ISSN 2411-4758 (Print) 2518-1602 (Online)

Native word in ethnocultural dimension, Drohobych, Posvit, 2021, pp. 74-87.

DOI: https://doi.org/10.24919/2411-4758.2021.213139

УДК 811.161.2’42:821.161.2.09(092)

\title{
ІНТЕР' СКТИВИ В МОВНІЙ КАРТИНІ СВІТУ ПОЕТА ПЕТРА КАРМАНСЬКОГО: СКЛАД, СЕМАНТИКА, ФУНКЦІОНУВАННЯ
}

\section{Марія ФЕДУРКО,}

доктор філологічних наук, професор, завідувач кафедри філологічних дисциплін та методики їх викладання у початковій школі, Дрогобицький державний педагогічний університет імені Івана Франка (Украӥна, Дрогобич) mfedurko@ukr.net

ORCID: http://orcid.org/0000-0002-1148-3867

Research ID: T-2629-2018 http://www.researcherid.com/rid/T-2629-2018

\section{Оксана ФЕДУРКО,} кандидат філологічних наук, доцент кафедри порівняльної педагогіки та методики викладання іноземних мов, Дрогобииький державний педагогічний університет імені Івана Франка (Украйна, Дрогобич) fedurko19@gmail.com

ORCID: http://orcid.org/0000-0002-2842-0555

Research ID: T-2591-2018 http://www.researcherid.com/rid/T-2591-2018

Статтю подано до редколегіï / The article is submitted to the editorial board: 30.09.2020.

Статтю опубліковано / The article is published: 22.02.2021.

У статті йдеться про вигуки й звуконаслідувальні слова як складники індивідуальної картини світу поета Петра Карманського. Розкрито поняття національно-мовної картини світу, визначено ї̈ стосунок до кониептуальної, індивідуальної та художньої картин світу. Показано, щуо в поетичному лексиконі Карманського представлені різні семантичні розряди інтер'єктивів і що їхні репрезентанти корелюють із загальним настроєм творів поета, особливостями його світобачення, світорозуміння й світовідчуття, иінностями його душі. Зазначено склад і специфіку вживання автором одиниць ичього лексико-граматичного класу.

Ключові слова: начіонально-мовна картина світу; художня картина світу; вигуки; звуконаслідувальні слова; Петро Карманський. 


\title{
INTERAJECTIONS IN THE LANGUAGE PICTURE OF THE WORLD OF THE POET PETRO KARMANSKY: STRUCTURE, SEMANTICS, FUNCTIONING
}

\author{
Mariia FEDURKO, \\ Doctor of Philology, Professor, Head of the Department \\ of Philological Sciens an teaching methods in elementary school \\ Drohobych Ivan Franko State Pedagogical University \\ (Drohobych, Ukraine) mfedurko@ukr.net
}

\section{Oksana FEDURKO,}

Ph.D. in Philology lecture Department of comparative pedagogy

and methods of teaching foreign languages,

Drohobych Ivan Franko State Pedagogical University

(Drohobych, Ukraine)fedurko19@gmail.com

The article substantiates the idea of the importance of taking into account the elements of the morphological level in structuring the linguistic picture of the world of the people in general and an individual in particular. Its purpose is to identify interjections in the poetic texts of P. Karmansky, to trace their structural-semantic and functional characteristics, the role in the representation of the individual-author picture of the world of the writer. The article reveals the concept of national-linguistic picture of the world, defines its relationship to the conceptual, individual and individual-author (artistic) pictures of the world. It is shown that the conceptual reproduces the elements of the world universe (objects, phenomena, values, guidelines) and the connections between them; linguistic represents them in linguistic categories, linguistic units and phenomena of speech; individual and individual-author is the result of rational and sensory comprehension of the environment embodied in the speech (texts) of specific individuals. The characteristic features of the creative manner of Petro Karmansky, his general attitude to depict the state of man, immersed in the world of his own soul. A soul disappointed by the injustice of the world, full of sorrow and feelings for its own fate and the fate of the native people. It is established that the lexicon of the poet Petro Karmansky presents almost all the semantic categories of exclamations and phonetic words, which are united by the concept and term interjection. It is determined that exclamations in the author's texts dominate over sound-imitating words. It is proved that emotional exclamations are marked by special activity; they outnumber other semantic digits as well. It is stated that the representatives of all semantic categories correlate in one way or another with the general mood of the poet's works - a singer of pain and sorrow, with the peculiarities of his worldview, his values and moral guidelines. The composition of these units is characterized in terms of origin (specific and borrowed) and on the basis of primary / secondary (non-derivatives and derivatives). Emphasis is placed on the specifics of their semantics, its dependence on the context. The peculiarities of the author's use of units of this lexical-grammatical class are analyzed. 
Key words: national-linguistic picture of the world, artistic picture of the world, interjections, sound-imitating words, Petro Karmansky.

Постановка проблеми. 3 утвердженням у сучасній науці загалом i мовознавчій зосібна антропоцентричної парадигми актуалізовано метафоричний за своєю природою термін «картина світу», запропонований вченими початку XX ст. - фізиком М. Планком (Планк, 1975, с. 615) та філософом і логіком Л. Вітгенштайном (Вітгенштайн, 1995, с. 26) для вивчення й систематизації наукових фактів. Поряд із ним особливого значення набули й ті, що засвідчують багатовимірність позначуваного феномена, головно концептуальна й мовна картини світу. Вони номінують не відокремлені, а взаємопов'язані сутності (Ю. Апресян, А. Вежбицька, В. Жайворонок, С. Срмоленко, Ю. Караулов, Г. Колшанський, Л. Лисиченко, О. Селіванова та ін.), адже концептуальна картина світу відтворює елементи світового універсуму та зв'язки між ними (Лисиченко, 2009, с. 12), тоді як мовна репрезентує ці елементи, також ціннісні орієнтири, життєві стратегії, сценарії поведінки «в мовних знаках, категоріях, явищах мовлення» (Селіванова, 2006, с. 441). Національно-мовна картина світу (або національно-мовний образ світу) - це семантично, каузально, ієрархічно структурований продукт колективної мовної свідомості, відбиток світосприймання, світовідчуття і світорозуміння народу, втілений у слові результат його духовної діяльності, що має в підмурку картину світу кожного зі своїх представників. Пізнання мовного образу світу знакових постатей України, до яких відносимо нашого краянина, поета та громадського діяча I-ої половини XX ст. Петра Карманського, - це, на нашу думку, одна зі сходинок до з'ясування особливостей і закономірностей структурування українськомовної картини світу.

Аналіз досліджень. На сьогодні стверджено, що мовна картина світу постає в процесах пізнання, соціалізації й комунікації особистостей. Вона поняття національно й культурно зумовлене, бо «виявляє типові риси національного розуміння й членування світу» (Гринюк, 2013), попри наявність у їі структурі універсальних ознак (Апресян, 1995, с. 39), також динамічним і історично змінним, позаяк «кожній історичній епосі притаманні свої способи та форми переживання світу» (Гуревич, 1984, с. 7), однак із збереженням ознак спадкоємності - «мінлива стійкість мовної картини світу», в інтерпретації С. Срмоленко (Срмоленко, 2009, c. 96). Водночас дослідники наголошують на важливості вивчення індивідуальних картин світу, унікальних для кожної особистості й зумовлених їі індивідуальними особливостями (Гринюк, 2013). В. Маслова 
актуалізує думку про специфічний вияв індивідуального образу світу, той, який репрезентують художні тексти того чи того письменника як представника певного етносу; вона пов'язана з національно-мовною та $є$ відбитком концептуальної картини світу, яку індивідуально-авторське сприйняття інтерпретує за допомогою відповідних мовних засобів (Маслова, 2004, с. 43). Під знаком такої настанови в українському мовознавстві досліджено особливості індивідуально-мовної концептосфери Петра Перебийноса (Бєлінська, 2019), проаналізовано визначальні риси ідіостилю Осипа Турянського (Кравченко-Дзондза, 2019), розкрито на основі творів Ю. Федьковича мовний світ гуцулів II-ої половини ХІХ ст. (Заїць, 2016).

3 огляду на те що «кожна мовна одиниця зорієнтована на концептуальний простір довкілля» (Жайворонок, 2002, с. 51), для пізнання своєрідності як національно-мовних, так і індивідуально-авторських картин світу важливо докладно вивчити роль різнорівневих мовних засобів у їхньому творенні, зокрема, і тих, що є виразниками емоційно-почуттєвих та оцінно-модальних чинників комунікації, бо що «заперечувано духовно, - писав Л. Фейєрбах, - це необхідно заперечувати також емоційно» (Фейєрбах, 1995, с. 183). Інтер'єктиви (від лат. interjectio ‘вигук'; звуконаслідувальні слова теж до них відносять) є тими одиницями мови, що безпосередньо спрямовані на передачу емоцій і почуттів мовців, їхніх оцінок об'єктів довкілля та проявів різноманітних реакцій на них. Вони, як і засоби інших мовних рівнів, долучаються до творення художнього цілого та вияву ментальних й морально-духовних настанов автора. Саме в контексті таких інтерпретацій вигуки та звуконаслідувальні слова сьогодні щораз активніше потрапляють у фокус дослідницької уваги (Вільчинська, 2017; Шуст, 2014).

Мета нашої статті - виявити інтер'єктиви в поетичних текстах П. Карманського, простежити їхні структурно-семантичні і функційні характеристики, роль у репрезентації індивідуально-авторської картини світу письменника.

Виклад основного матеріалу. «Що б людина не називала і не виражала, - вона завжди розкриває власну сутність, - стверджував Л. Фейєрбах, - тому мова є критерієм того, на якому рівні перебуває людська культура» (Фейербах, 1995, с. 86). Такого ж погляду дотримувався й М. Гайдеггер: «Я є те, що я мовлю» (Хайдеггер, 1993, с. 54). Тож, приступаючи до вивчення мовної картини світу кожного з письменників чи певних ії елементів, важливо усвідомлювати, що в ній він виявляв себе, власні інтелектуальні обшири й моральні імперативи, власне розуміння світу і ставлення до стану речей у ньому. 
П. Карманський увійшов у літературу на початку ХХ ст. $з$ гострим відчуттям «потреби оновлення українського слова, зближення його 3 новітніми течіями світової літератури» (Голомб, 1996, с. 7). А ще - виразним представником епохи fin de sciécle, перейнятої песимізмом, заглибленістю у світ індивідуальних переживань, пропагандою безнадії й смутку. Від першої збірки «3 теки самоубийця. Психологічний образок у замітках і поезіях» (1899) поет заявив про себе як про людину «м'якого, вразливого серця й трагічного світовідчування» (Голомб, 1996, с. 5), людину наче й виокремлену зі світу, але нерозривно пов'язану з ним, співця болю і страждань - власних і вселюдських: Bce пусте - святий лии людський біль (с. 89). Як справжній митець, він еволюціонував - від заглиблення у стан власної душі до вболівання за життя рідного народу й долю України, «від суспільної індиферентності до високого пафосу патріотичних і громадянських почуттів» (Голомб, 1996, с. 22). I на всіх етапах свого духовного зростання Карманський ніколи не був людиною байдужою, неемоційною, а завжди чутливою, неспокійною, пристрасною, що гостро переживає власні й народні болі. Це, відповідно, отримувало вияв у його поетичному лексиконі (Федурко, 2018). Не бракує в ньому також вигуків і звуконаслідувань - мовних одиниць, покликаних відтворювати всю гаму почуттів особистості, іiі різноманітні емоційні реакції на довкілля, а також її волевиявлення.

Лінгвістична кваліфікація вигуків доволі суперечлива: за ними то визнають статус лексико-граматичного класу, хоч і виводять із переліку повнозначних і службових частин мови; то зараховують до системи лексичних засобів мови, але у статусі еквівалентів синтаксично нечленованих речень, уживаних для формування оцінно-модального плану висловлень; то вважають реченнєвими одиницями, проте такими, що тільки віддалено співвідносні з судженнями, бо, відбиваючи суб'єктивне ставлення до об'єктивного світу, є всього лиш його емоційними еквівалентами (Безпояско та ін., 1993, с. 318-319). Вони не однорідні за структурою, походженням і функційними характеристиками; частина 3 них (насамперед первинні одиниці) виявляє тенденцію до багатозначності, що засвідчує наявність у вигуків семантики, але нечіткої, яка потребує уточнення контекстом. Згадане підтверджують і поетичні тексти П. Карманського.

У віршах книги «Ой люлі, смутку...», що репрезентує твори всіх збірок поета, виявлено одиниці обох класів інтер'єктивів - вигуки ( $\boldsymbol{O} \boldsymbol{x}$, чому та Сила, / Що в плоть вливає іскру Духа,/ Чому вона в мені зродила/ Такий вогонь - c. 66) та звуконаслідувальні слова - як ті, що передають звукові сигнали тварин, механізмів чи фізіологічні прояви людини, так 
i ті, що характеризують звукові ознаки дій, рухів (по-іншому, вербоїди), пор.: Куку! Куку! Дзвінко ллється/ Кришталевий звук./ Звук несеться, гай смісться./ Серие стук-стук-стук... (с. 53), проте з виразним домінуванням перших: із 209 зафіксованих слововживань тільки 20 належить звуконаслідувальним словам (ха-ха!, га-га!, пугу!, куку!, ія!, кумкум!, какаду!, пас!, візо!, сам!, стук!, гульк!, бац!, кап!). Серед вигуків переважають первинні: o!, ой!, гей! циить! (u̧итьте!), геть!, годі!, нуте!, нум!, пробі!, проте панує над усіма вигук ох! - 33 уживання. Трапляються й одиничні слововживання - вигуки ax!, ex!, em!, eй!, ого!, га!, наприклад: «Em, багато хочеш знати! Фойсу в руки та махай!» (с. 235); Втім озвався хтось з порога: «Ей, сгомосиьь, не грішіть!» (с. 236).

Якщо характеризувати виявлені в текстах Карманського інтер'єктиви $з$ погляду походження, то належить ствердити, що переважають питомі одиниці на тлі нечисленних запозичень (амінь!, ура!, осанна!, nac!, візо!), серед яких трапляються слова в чужомовному графічному оформленні, приміром, ave!, bis!, пор.: Амінь! Кажу вам, щзо проб'є година (c. 210); Осанна вам брати! Ликуй, народе мій (с. 184) та А як на горах заридає туга/ Вечірніх дзвонів, ти співаєш: «Ave!» (c. 242); Вis, блазню коханий, bis, брате, bis, чорте! Пусте всі ідеї! Диви, я сміюся!..(с. 161). Останнє речення засвідчує актуальність інтер'єктивованих форм, тобто утворених шляхом переходу повнозначних слів різних частин мови, зокрема дієслів, у клас вигуків: діалектною формою наказового способу диви, також дивіть (Тоді на цілу Русь итучний твій жаль голосить: Дивіть! Ось б'ють мене, $і$ я тому сумний... - с. 164, норм. дивись!, дивіться!) ліричний герой не лише привертає увагу читача (адресата) до висловленого, а й сам емоційно реагує на нього. Це підтверджує думку, що синкретизм, тобто суміщення в одній словоформі ознак репрезентантів різних лексико-граматичних класів, становить одну з визначальних прикмет цього різновиду одиниць. До них в досліджуваному матеріалі належать іменникові словоформи Боже!, Господи!, леле!, горе! слава!, хвала!, дієслівні скажіть!, бач!, гляньте!, глядіть!, диви!, дивіть!, прощзайте!, прислівникова славно!.

Нерідко автор уживає зазначені одиниці разом зі словами-поширювачами: займенниками, прикметниками, частками, вигуками. Це так звані вигукові фразеологізми (або фразеологізовані вигуки): $A$ серце ниє, ниє, ниє. Туман - гроза... О горе! Горе! (с. 85); А все ж таки щзаслив, хто може/ На вид палаючих кострів/ Сказати радісно: "Мій Божее, I я в геєнні иій горів» (с. 258); Стали прощзатись. Господи правий!/ Хто змірить глубінь смутку-розлуки/ Хлопського серия? (с. 73); О Боже мій! Чи я спочину/ Від тих незмірних мук? (с. 48); Ну й скажіть, чи ми 
такі смішні?/ Й дивіть, ті люди нас медведями вважають!... (с. 173); А скільки ие стояло/ I труду, і гроша (Не свого - щчо робить!) (с. 180); Невже об лід людства розіб 'ється таран/ Кривавих наших мольб? Най буде Божса воля... (с. 189). Серед них трапляються й чужомовні: Щойно станеш квіти рвати,/ вже й неси готов вінецьь:/ Гаснуть очі,/ Час вмирати./ Чуєш клич?/ Mетепtо mоri! (с. 56); Плиніте ж, дні горя, плиніть, безталанні,/ До тихої Лети... Evviva la morte! (c. 139). До слова, вигуковий фразеологізм memento mori! 'хотів би вмерти' виконує функцію епіфори у «Стиху III» (цикл «Надгробні стихарі», збірка «Ой люлі, смутку»), а evviva la morte! 'хай живе смерть' формує анепіфору (кільце): він ужитий у назві вірша та в його фіналі (цикл «Тіням мами», збірка «Пливем по морі тьми»). Загалом, використання епіфори, кільця й анафори, - одна з виразних прикмет ідіостилю Петра Карманського. У їхньому складі виявляємо нерідко вигуки, які підсилюють відповідне емоційне звучання тексту - див., для прикладу, вірш «Над колискою» (цикл «На сій долині сліз», збірка «Ой люлі, смутку», сама назва якої містить вигук):

Люлі, синку! Сонце скрилось,

Потонуло в темний бір;

Темне небо заясніло,

Запінилось морем зір.

Спи, дитинко! Люлі, люлі.

Люлі, синку! Най повіє

Над тобою легіт мрій;

Усміхнися, наче сонце,

Ясна зоре, раю мій!

Спи, дитинко! Люлі, люлі.

Мікроконтексти на взірець Бо успіху ичілий секрет/ $С$ хист на все мовчати,/ I берегти своїх діст,/ I часом «bis» кричати (с. 348) та Paдіємо, як хтось до нас «тю-тю!» повість,/ A навіть $i$ тод $i$, як злають бідолаху (c. 173) засвідчують факт підвищення морфологічного статусу інтер'єктивів, набуття ними ознак повнозначної частини мови (в наведених прикладах - іменника).

Варто вказати на таку особливість уживання Карманським деяких інтер'єктивів (гей!, гай! люлі!, цчить! (циитьте!), ура!, амінь!, ха!, га!, гоn!, куку!, ква!, какаду!), як їхній повтор чи подвоєна, а то й потроєна вимова $з$ метою посилення емоцій і волевиявлень: Люлі, люлі, скорбні думи/ Ще й до вас всміхнеться май (с. 54) < ..> А там садок, в садку хатина, / А в ній... Цить, мріє, цить (с. 33); Ура у бій! Ура! Ура! (с. 224); Амінь, амінь! Поругана надія/ Обернеться в трагедію Свропи! (с. 191); 
Гай-гай! Здається, переснилось/ Оичхх злиденних тридиять літ (с. 317). Повторами звуконаслідувань автор зазвичай підкреслює тривалість якогось процесу чи дії, увиразнює їх, пор.: По нім спливає дощ обильною росою:/ Бац... кап... бац... кап... Паде, як з рани тепла кров... (с. 152); Ходить в коло й кричить: Какаду! Какаду!/ Мені добре з моєю нудьгою (с. 172). Часом він поєднує ці два різновиди слововживання: Я на моїй скалі стою, як демон мести,/ I глумлюся тобі: га-га! га-га! га-га! (c. 155), домагаючись не лише уточнення відповідних контекстів, а й посилення їхньої експресивності.

В. Горпинич, обгрунтовуючи граматичний статус вигуків, серед їх диференційних синтаксичних ознак називає препозитивність: ці одиниці, каже він, «завжди стоять на початку висловлення (речення)», протиставляючись у цьому плані сполучникам, прийменникам, часткам (Горпинич, 2004: с. 303). Поезії П. Карманського спростовують категоричність цього твердження, адже у них виявляємо інтер'єктиви не лише на початку висловлень, а й у середині чи наприкінці їх, пор.: $\boldsymbol{O}$ Боже мій! Чи я спочину/ Від тих незмірних мук (с. 48); Останній посів-Боже мій!/ Який гіркий він видав плід! (с. 340); Збудився я; душа бажала/ Полинуть в рай... О Боже! (с. 23). Різнопозиційність цих одиниць у досліджуваних текстах - явище не регулярне, однак і не поодиноке, див. ще: < ...> і ніби ненароком/ Швиденько, бач, завів, з хижацтвом женихання/ Та й полюбив як стій козаџькеє гуляння (с. 183); А ми ждемо на нашу зорю./ I даром - леле! Доки ж ждати? Коли загляне в нашу хату/ Проміння волі? (с. 66); Гайда! Гайда! Не слід зітхати ... Весело ж, гай! - ні! нииком, тихо! (с. 26).

Останній мікроконтекст засвідчує ще один (і доволі активний) спосіб уживання Карманським інтер'єктивів - у взаємодії, і не завжди одиниць того самого семантичного розряду: Пробі! Я плачу!.. Я ридаю!../ Цить, серие, цить! Настане хвиля -/ Всю їдь віків: отрую глуму, І лють скорбот, i дур похмілля/ Зіллю в одну болючу думу <...> (с. 86). Це неодмінно посилює емоційно-експресивні характеристики тексту, допомагаючи авторові передати ті тривоги, що поселилися в його серці, і ті шквали почуттів, що шматують його душу.

Не менш барвистою є семантична палітра інтер'єктивів, виявлених у досліджуваних текстах: тут представлені одиниці майже всіх виділюваних розрядів. Почнемо з найчастотнішого - емоційного.

Активність емоційних вигуків вмотивована загальним настроєм лірики поета, постійним неспокоєм його відкритої до людських страждань душі. Не стверджуватимемо, що він уживає кожен із наявних у системі мови інтер'єктивів цього різновиду. Навпаки, виявляємо в його віршах 
тільки вигуки о!, ой!, ох! як найчастотніші, також гай!, Боже!, Господи!, леле!, горе!, амінь!, ура!, осанна!, хвала!, славно!, ий-богу!, поодинокі ax!, ex!, em!, eй!, ого!, га!, вигукові фразеологізми Боже мій!, о горе!, о Боже!, Господи правий!, о леле! тощо. Вигуки о!, ой!, ох! багатозначні й можуть уживатися для вираження прямо протилежних почуттів (від жалю, суму, горя, досади, осуду, розчарування, спричинених непростими обставинами життя чи нереалізованими мріями й бажаннями ліричного героя: $\boldsymbol{O x}$, як тоді хотілося заглянуть/ B ті сірі очі, щуо не знали сну!.. (с. 370) - до радості, здивування, захоплення, подиву тощо: $\boldsymbol{O x}$, чому та Сила/ Що в плоть вливає іскру Духа,/Чому вона в мені зродила/ Такий вогонь? (с. 66). П. Карманський використовує їх здебільшого в першій функції, до того ж у віршах різних своїх збірок. Власне таке їх семантичне потрактування підказує контекст, передусім значеннєві плани вжитих у ньому одиниць інших лексико-граматичних класів, також синтаксична структура висловлення, його інтонаційний малюнок, як у вірші «Сумно ллються звуки цитри...». Ось його фінальна строфа:

$\boldsymbol{O x}$, як тяжко коло серияя/

Від тяжкої муки!

$\boldsymbol{O} \boldsymbol{x}$, заграй же, моя ичитро/

Сумні, сумні звуки... (с. 27).

Лексеми та їх сполуки тяжко, тяжкої муки, сумні звуки допускають пов'язання вигука ox! тільки з семантикою болю й страждання: душа ліричного героя змучена розлукою з коханою, вона страждає через неможливість зустрічатися та бачитись. Невипадковими є повтори вигука $о x !$ та лексеми сумні в цій строфі, також інтонація обох речень-висловлень - спершу оклична, коли ліричний герой наче випустив із серця зойк, а далі незавершеності, коли він уже нічого не очікує від долі, окрім розпачу й страждань.

Побіч вигуків, спрямованих на вираження домінантних почуттів болю-туги-розпачу, у текстах П. Карманського натрапляємо на емоційні вигуки, співвідносні з семантикою сумніву: Гай, гай! Hixmo не знає,/ Що з серия викреше нам час! (с. 214); попередження-погрози: О Росіє під чоботом Миколи!/ О, прощення нема тобі ніколи!.. (с. 369) (якщо в першому випадку вигук $о$ ! вжито для підсилення звертання, то в другому - для передачі цього значеннєвого відтінку); захоплення: Oй, нема то краю, краю над ті рідні села -/ Такі серцю запахущі, як зиілющі зела! (c. 250); радості від замилування природою: Усе засипляє, а серце так б'ється.../ Так гарно, так тужно -мій Боже! (с. 98), легкої іронії: Ми не зійдемося: ти пані,/ Від мене ж (ах!) заносить піт./ Хміль серия, навіть на екрані,/ Цінують нижче, ніж обід...(с. 258) чи навіть злої на- 
смішки: І глядять на раба, і сміються над ним:/ «Ох, який же ти, брате наш, бідний!» (с. 173).

Одиниці вокативного підрозряду емоційних вигуків (npoбi!, горе!, амінь!, Боже!, осанна!), до яких зараховуємо й вигукові фразеологізми (о горе!, Боже мій!, о Боже!, о Боже мій!, Боженьку святий!, о Христе!, так щзо ж!) спрямовані в аналізованих текстах не так на безпосереднє вираження почуттів, настроїв, емоцій, як на емоційну характеристику подій, станів, явищ, фактів, осіб або їхню оцінку: Їй-богу, рація! Якийбо я дурний...(с. 164); Повір, не виллється надармо жертва крови.../ Ідеш? Ох, Боже!!. Йди! Взиває рідний край! (с. 188); Осанна гордим Лицарям! Ми вольні (с. 186). Цю ж функцію виконують і магічні волюнтативи, ужиті в ролі вигуків (най буде Божа воля!, крий нас Боже!, ради Бога!, Господь з тобою!, Пречиста твій покров): Діти вчити - крий нас Боже!/ Краще з шнуром під піньор... (с. 238). Показовим у цьому плані є початок вірша «Українська балада» (збірка «Al fresco»):

Тату, тут тісно! Дух мій в задумі,

В груді жевріє вічна геєнна.

Виллю все горе в пламенній думі,

Най заридає Бог і вселенна.

Господь з тобою! Клята година

Пісню збудила. Бідна дитина... (с. 164).

У текстах деяких віршів Карманського фразеологізований вигук повертає собі лексичне значення й набуває ознак вокативного речення, у якому нероздільно представлені як емоції і почуття, так і вказівка на адресата мовлення: Ох, Боженьку святий! I за яку це кару/ Мене ти вбрав в страшне, важке ярмо оче? (с. 171); Ох, Отче наш благий, котрий цариш на небі/ I вказуєш цүілій вселенній правий путь!/ До тебе ми з низин звертаємся в потребі/ I молимо з глибин: ласкав нам, Батьку, будь! (с. 196).

Для спонукальних інтер'єктивів характерна семантика емотивного волевиявлення. Вони виражають наказ, спонукання, заохочення до діiі, бажання привернути увагу до когось чи чогось. Це непохідні вигуки геть!, соб!, цуабе!, нум!, годі!, циить!, (цчитьте!), похідні диви!, дивіть!, гляньте!, глядіть!, рятунку!, часом підсилені частками: I їжджу на громадськім возі,/ Вигукуючи: соб! цабе! (с. 260); Геть, нікчемний дивовиже! Сього чей ніхто не їсть... (с. 166); За нами тільки пес завиє -/ Вона ж прокляла... Нум, щуосили (с. 26); Та циить! Нехай тобі не вадить/ Мій жаль і туга за тобою (с. 76); Рятунку!... Глухо, зимно $i$ спокійно/ Валить на мене сіра повінь смути <... (с. 111); Ось гляньте! Щирий труд приніс нам зерна плоду:/ Від Сяну по Кавказ «Україна» 
- глядіть! (c. 180). Хоч у досліджуваних текстах вони представлені невеликою кількістю одиниць, проте деякі з них (годi!, uуить!) доволі частотні. Багатозначний вигук гей!, який граматисти наводять у переліку спонукальних (Горпинич, 2004: с. 305), Карманський уживає також для вираження емоцій - зажури: Гей, пристроїв я образ твій в гірлянди/Блідих конвалій, ірисів і рожі,/ I враз з тоскою влив я в черти гожі/ Ніжну принаду гордої троянди (с. 109); жалю за минулим: Гей, гей, пішов ти мій безцвітний маю,/ I не оставив навіть снів по собі... (с. 136).

Із розряду апелятивних інтер'єктивів, які вживаються в мовленні для привернення уваги співрозмовника, налагоджння з ним контакту, Карманський уживає (щоправда нечасто, бо вони передбачають діалогічні контексти), тільки гей!, гов!, бач!, ей!: Гей, поспішайте, їдте скорим ходом, / Щоб за минулим загубився слід! (с. 295); I крикнув: «Буде, діти! Гов! (c. 356); Та й честь у нас дають лиш вибраним, а ми -/ А ви, мені здаєсь, не з тої, бач, родини (с. 169). До апелятивних вигуків близькі етикетні вислови, які дехто з дослідників виділяє в окремий семантичний розряд (Горпинич, 2004: с. 305). Їм властиві лаконічність і стандартність форми, вказівка на соціальний контекст, експліцитність протиставлення «адресант-адресат». Ці одиниці Карманський використовує в основному для вираження привітання й прощання: Фальшивий тон - прощзальні слези:/ «Бувай здоров...» - «Бувай здорова...» (с. 131); 3 могил несесь/ Солодкий клич... Кругом туман -/ Добраніч вам! Добраніч всім! (с. 55); Зійилися всі до мене, дружно/ Стискають руки: славайсу! (с. 300).

У словнику П. Карманського, як згадувано, звуконаслідувальні слова представлені не так численно, як вигуки, однак усіма семантичними розрядами, тобто на позначення: 1) звукових виявів птахів і тварин - свійських та диких: I звідки в тих поетів сум,/ Ті «перли сліз», проміння, злото?/ Кум-кум! кум-кум! кум-кум! кум-кум!/ Нема, як нашеє болото (с. 168); Проснулись сови і гукають: пугу! (с. 189); 2) звукових ознак предметів і явищ дійсності: Стук! - хто там? - Я твій Смуток! (c. 26); 3) звукових ознак дій та рухів: Гon! Гоn! мій коню,/ в степ, як море (с. 265); 4) звукових фізіологічних процесів, відтворюваних мовним апаратом людини: I зазираємо жадно, з ичікавістю/ В яр, де регоче дійсність: ха-ха! (с. 255); Ходить, блудить, гей повія,/ $i$ з нудьги реве: ія! (c. 165).

Висновки та перспективи подальших досліджень. Для з'ясування специфіки національно-мовної картини світу важливо досліджувати індивідуальні й індивідуально-авторські (художні) картини світу: тільки через індивідуальне, конкретно-мовленнєве пізнаємо спільне, загальномовне. Лексичні й граматичні особливості ідіостилю Петра Карман- 
ського - представника нової течії в українському літературному процесі початку XX ст. - слугують надійним джерелом для розбудови як його мовного образу світу, так і нашого народу загалом. Перспективним уважаємо вивчення елементів інших підсистем мовного світу П. Карманського для осягнення особливостей структурування українськомовної картини світу.

\section{СПИСОК ДЖЕРЕЛ}

Карманський, П. (1996). Ой люлі, смутку... (Поезіï). Упор. текстів, передмова та примітки Л. Г. Голомб. Ужгород.

\section{СПИСОК ЛІТЕРАТУРИ}

Апресян, Ю. Д. (1995). Образ человека по данным языка: попытка системного описания. Вопросы языкознания. № 1, $38-42$.

Безпояско, О.К., Городенська К.Г. \& Русанівський В.М. (1993). Граматика української мови. Морфологія. Київ : Либідь.

Бєлінська, В. Є. (2019). Індивідуально-мовна концептосфера П. Перебийноса. Лінгвістичні дослідження, 188 - 196.

Вільчинська, Т. П. (2017). Інтер'єктиви як репрезентанти суб'єктивних оцінок у поетичній творчості Богдана Лепкого. Наукові записки ТНПУ: Літературознавство. Вип. 47, $311-320$.

Вітгенштайн, Л. (1995). Tractatus Logiko-Philosophicus. Філософські дослідження. Київ : Основи.

Голомб, Л. (1996). Митець незвичайної долі. П. Карманський. Ой люлі, смутку... (Поезії). Ужгород : Гражда, 3 - 22.

Горпинич, В. О. (2004). Морфологія украӥнської мови : Підручник для студентів вищих навчальних закладів. Київ : ВП «Академія».

Гринюк, А. (2013). Языковая картина мира как философская проблема [Электронный ресурс]. Credo New. Tеоретический журнал. Взято 3 http://www.intelros. $\underline{\mathrm{ru} / \mathrm{readroom} / \mathrm{credo} \text { new/k4-2013/21499-yazykovaya-kartina-mira-kak-filosofskaya- }}$ problema.html.

Гуревич, А. Я. (1984). Категории средневековой культуры. Москва : Искусство.

Єрмоленко, С. Я. (2009). Мінлива стійкість мовної картини світу. Мовознавство. №3-4, $94-103$.

Жайворонок, В. В.(2002). Проблема концептуальної картини світу та мовного ії відображення. Культура народов Причерноморья. №32, 51 - 53.

Заїць, В. (2016). Мовна картина світу гуцула другої половини ХІХ століття (за художньою та епістолярною спадщиною Ю. Федьковича). Науковий вісник Ужгородського університету. Серія: Філологія. Випуск 2 (36), 352 - 355.

Кравченко-Дзондза, О. (2019). Особливості мовного стилю Осипа Турянського. Рідне слово в етнокультурному вимірі: зб. наук. пращь. Дрогобич: Посвіт, 133 - 141. DOI: 10.24919/2411-4758.2019/17777. 
Лисиченко, Л.А. (2009). Лексико-семантичний вимір мовної картини світу. Харків : Видавнича група «Основа».

Маслова, В. А. (2004). Поэт и культура: концептосфера Маринь Цветаевой. Москва : Флинта : Наука.

Планк, М. (1975). Единство физической картины мира. М. Планк. Избранные труды. Москва : Наука, 613 - 633.

Селіванова, О. О. (2011). Лінгвістична енциклопедія. Полтава : Довкілля-К.

Федурко, М. (2018). Лексичні домінанти збірки Петра Карманського «Ой люлі, смутку». Проблеми гуманітарних наук. Випуск 42, 148 - 157.

Фейербах, Л. (1995). Сочинения : В 2 т. Т. 1. Москва : Наука.

Шуст, Л. (2014). Вигуки та вигукові фразеологізми в поетичній творчості Т. Шевченка. Наукові записки Національного університету «Острозька академія». Серія «Філологічна». Випуск 47, $184-187$.

Хайдеггер, М. (1993). Бытие и время. Москва : «Республика».

\section{REFERENCES}

Apresyan, Yu. D. (1995). Obraz cheloveka po dannym yazyka: popytka sistemnogo opisaniya [Human image according to language data: an attempt at a systemic description]. Voprosy yazykoznaniya - Linguistic issues. № 1, 38 - 42. [in Ukrainian]

Bezpoiasko, O.K., Horodenska K.H. \& Rusanivskyi V.M. (1993). Hramatyka ukrainskoi movy. Morfolohiia [Grammar of the Ukrainian language. Morphology]. Kyiv : Lybid. [in Ukrainian]

Bielinska, V. Ye. (2019). Indyvidualno-movna kontseptosfera P. Perebyinosa [Individual-linguistic conceptosphere of P. Perebyinos] Linhvistychni doslidzhennia - Linguistic researches, 188 - 196. [in Ukrainian]

Vilchynska, T. P. (2017). Interiektyvy yak reprezentanty subiektyvnykh otsinok $\mathrm{u}$ poetychnii tvorchosti Bohdana Lepkoho [Interactives as representatives of subjective assessments in the poetic work of Bohdan Lepky]. Naukovi zapysky TNPU: Literaturoznavstvo. Vyp. 47 - Scientific notes of TNPU: Literary Studies. Issue 47, 311 - 320. [in Ukrainian]

Vitgenshtain, L. (1995). Tractatus Logiko-Philosophicus. Filosofski doslidzhennia [Tractatus Logiko-Philosophicus. Philosophical research]. Kyiv : Foundations. [in Ukrainian]

Holomb, L. (1996). Mytets nezvychainoi doli [An artist of unusual destiny.]. P. Karmanskyi. Oi liuli, smutku... (Poezii) - P. Karmansky. Oh Luli, sorrow... (Poetry). Uzhhorod : Grazhda, 3 - 22. [in Ukrainian]

Horpynych, V. O. (2004). Morfolohiia ukrainskoi movy : Pidruchnyk dlia studentiv vyshchykh navchalnykh zakladiv [Morphology of the Ukrainian language: A textbook for students of higher educational institutions.]. Kyiv : VP «Akademiia» [in Ukrainian]

Grinyuk, A. (2013). Yazykovaya kartina mira kak filosofskaya problema [The linguistic picture of the world as a philosophical problem]. Credo New. Teoreticheskiy zhurnal - Credo New. Theoretical journal. Retrieved from http://www.intelros.ru/ 
readroom/credo new/k4-2013/21499-yazykovaya-kartina-mira-kak-filosofskayaproblema.html. [in Russian]

Gurevich, A. Ya. (1984). Kategorii srednevekovoy kultury [Categories of medieval culture]. Moscow : Art. [in Russian]

Iermolenko, S. Ia. (2009). Minlyva stiikist movnoi kartyny svitu [Changing stability of the linguistic picture of the world]. Movoznavstvo - Linguistics. №3-4, $94-10$ [in Ukrainian]

Zhaivoronok, V. V. (2002). Problema kontseptualnoi kartyny svitu ta movnoho yii vidobrazhennia [The problem of the conceptual picture of the world and its linguistic reflection]. Kultura narodov Prychernomoria - Culture of the peoples of the Black Sea region. № 32, 51 - 53 [in Ukrainian]

Zaits, V. (2016). Movna kartyna svitu hutsula druhoi polovyny XIX stolittia (za khudozhnoiu ta epistoliarnoiu spadshchynoiu Yu. Fedkovycha) [Linguistic picture of the Hutsul world of the second half of the XIX century (according to the artistic and epistolary heritage of Yu. Fedkovych)]. Naukovyi visnyk Uzhhorodskoho universytetu. Seriia: Filolohiia - Scientific Bulletin of Uzhhorod University. Series: Philology. Issue 2 (36), 352 - 355 [in Ukrainian]

Kravchenko-Dzondza, O. (2019). Osoblyvosti movnoho styliu Osypa Turianskoho [Features of Osip Turyansky's language style.]. Ridne slovo v etnokulturnomu vymiri: zb. nauk. prats - Native word in ethnocultural dimension: Coll. Sciense, $133-141$. DOI: 10.24919/2411-4758.2019/17777. [in Ukrainian]

Lysychenko, L.A. (2009). Leksyko-semantychnyi vymir movnoi kartyny svitu [Lexical and semantic dimension of the linguistic picture of the world]. Kharkiv: Vydavnycha hrupa «Foundation». [in Ukrainian]

Maslova, V. A. (2004). Poet i kultura: kontseptosfera Mariny Tsvetaevoy [Poet and Culture: Marina Tsvetaeva's Concept Sphere]. Moscow: Flinta: Sciences/ [in Russian]

Plank, M. (1975). Yedinstvo fizicheskoy kartiny mira [The unity of the physical picture of the world]. M. Plank. Izbrannye trudy-Selected Works. Moscow : Sciences, 613 - 633. [in Russian]

Selivanova, O. O. (2011). Linhvistychna entsyklopediia [Linvistic Encyclopedia]. Poltava : Dovkillia-K. [in Ukrainian]

Fedurko, M. (2018). Leksychni dominanty zbirky Petra Karmanskoho «Oi liuli, smutku» [Lexical dominants of Peter Karmansky’s collection «Oi liuli, smutku»]. Problemy humanitarnykh nauk. Vypusk 42. - Problems of humanities. Issue 42, 148 157. [in Ukrainian]

Feyerbakh, L. (1995). Sochineniya. V 2 t. T. 1. [Works: In 2 volumes.Vol. 1.]: Moscow: Sciences. [in Russian]

Shust, L. (2014). Vyhuky ta vyhukovi frazeolohizmy v poetychnii tvorchosti T. Shevchenka [Vyhuky ta vyhukovi frazeolohizmy $\mathrm{v}$ poetychnii tvorchosti T. Shevchenka]. Naukovi zapysky Natsionalnoho universytetu «Ostrozka akademiia». Seriia «Filolohichna». Vypusk 47 - Naukovi zapysky Natsionalnoho universytetu «Ostrozka akademiia». Series «Philological». Issue 47, 184 - 187. [in Ukrainian]

Khaydegger, M. (1993). Bytie i vremya [Being and time]. Moscow: «Respublika». [in Russian] 